\title{
In vivo and in vitro studies on heavy metal tolerance in Sesbania grandiflora $\mathbf{L}$.
}

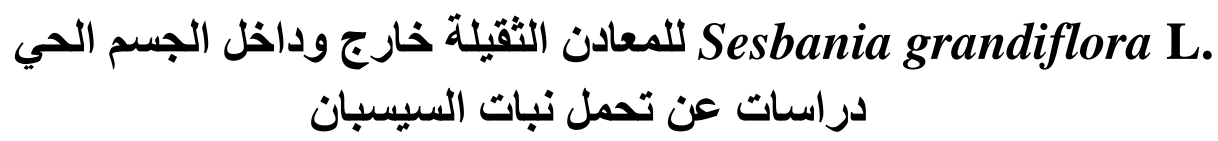

Kadhim M. Ibrahim

Shaimaa A. Yousir

Biotechnology Dept. /College of Science / Al-Nahrain University

$$
\text { قسم الثقنيات الاحيائية /كلية العلوم/جامعة النهرين }
$$

\begin{abstract}
Several experiments were carried out to study heavy metal tolerance in tissue cultures or whole plants of $S$. grandiflora., Callus was induced and maintained on modified Murashige and Skoog, 1962 medium (MS) supplemented with (0.5)mg/l benzyl adenine and (2)mg/l 2,4-phenoxy acetic acid . Heavy metals $(\mathrm{Cd}, \mathrm{Co}, \mathrm{Cu}, \mathrm{Cr}$ or $\mathrm{Zn}$ ) were added to the culture medium at different concentrations as contamination agents. In order to asses the effect of these heavy metals on seed germination; seeds were sown in soil contaminated with different concentrations of heavy metals for 3 weeks. Atomic Absorption Spectrophotometer was used for analysis of samples taken from whole plants and callus cultures. Results showed that callus fresh weight decreased with increasing heavy metal concentration in cultural medium. Germination percentages and plant heights increased over time. However, a reduction occurred in these parameters with increasing heavy metal levels. Percentages of metals accumulated in calli were $(0.001,0.011,0.012$ and $0.013 \%)$ at $(0.0,0.05,0.075$ and 0.1$) \mathrm{mg} / \mathrm{l} \mathrm{Cd}$ respectively; $(0.001,0.008,0.016$ and $0.006 \%)$ at $(0.0,0.1,0.25$ and 0.5$) \mathrm{mg} / \mathrm{l}$ Co respectively; $(0.001,0.020,0.034$ and $0.015 \%)$ at $(0.0,0.075,0.2$ and 0.5$) \mathrm{mg} / \mathrm{l} \mathrm{Cu}$ respectively; $(0.001,0.013,0.012$ and $0.010 \%)$ at $(0.0,0.25,0.4$ and 0.5$) \mathrm{mg} / \mathrm{l} \mathrm{Cr}$ respectively and $(0.027,0.051,0.059$ and $0.056 \%)$ at $(0.0,0.75,1.0$ and 1.5$) \mathrm{mg} / \mathrm{l} \mathrm{Zn}$ respectively. Percentages of metals accumulated in whole plants were $(0.08,0.55,1.11,0.83$ and $0.44 \%)$ at $(0.0,1.0,2.0$, 3.0 and 4.0$) \mathrm{mg} / \mathrm{Kg}$ soil Cd respectively; $(0.11,0.22,0.55,0.47$ and $0.44 \%)$ at $(0.0$, 15.0, 30.0 45.0 and 60.0) $\mathrm{mg} / \mathrm{Kg}$ soil Co respectively; $(0.01,0.10,0.57,0.58$ and $0.72 \%)$ at $(0.0,25.0,50.0,75.0$ and 100.0$) \mathrm{mg} / \mathrm{Kg}$ soil $\mathrm{Cu}$ respectively. $(0.08,0.80$, 1.28, 1.31 and $0.88 \%)$ at $(0.0,25.0,50.0,75.0$ and 100.0$) \mathrm{mg} / \mathrm{Kg}$ soil $\mathrm{Cr}$ respectively and $(0.06,1.11,1.20,1.83$ and $2.22 \%)$ at $(0.0,100.0,200.0,300.0$ and 400.0$) \mathrm{mg} / \mathrm{Kg}$ soil $\mathrm{Zn}$ respectively.
\end{abstract}

Keywords: Sesbania grandiflora, heavy metals tolerance, tissue cultures. 


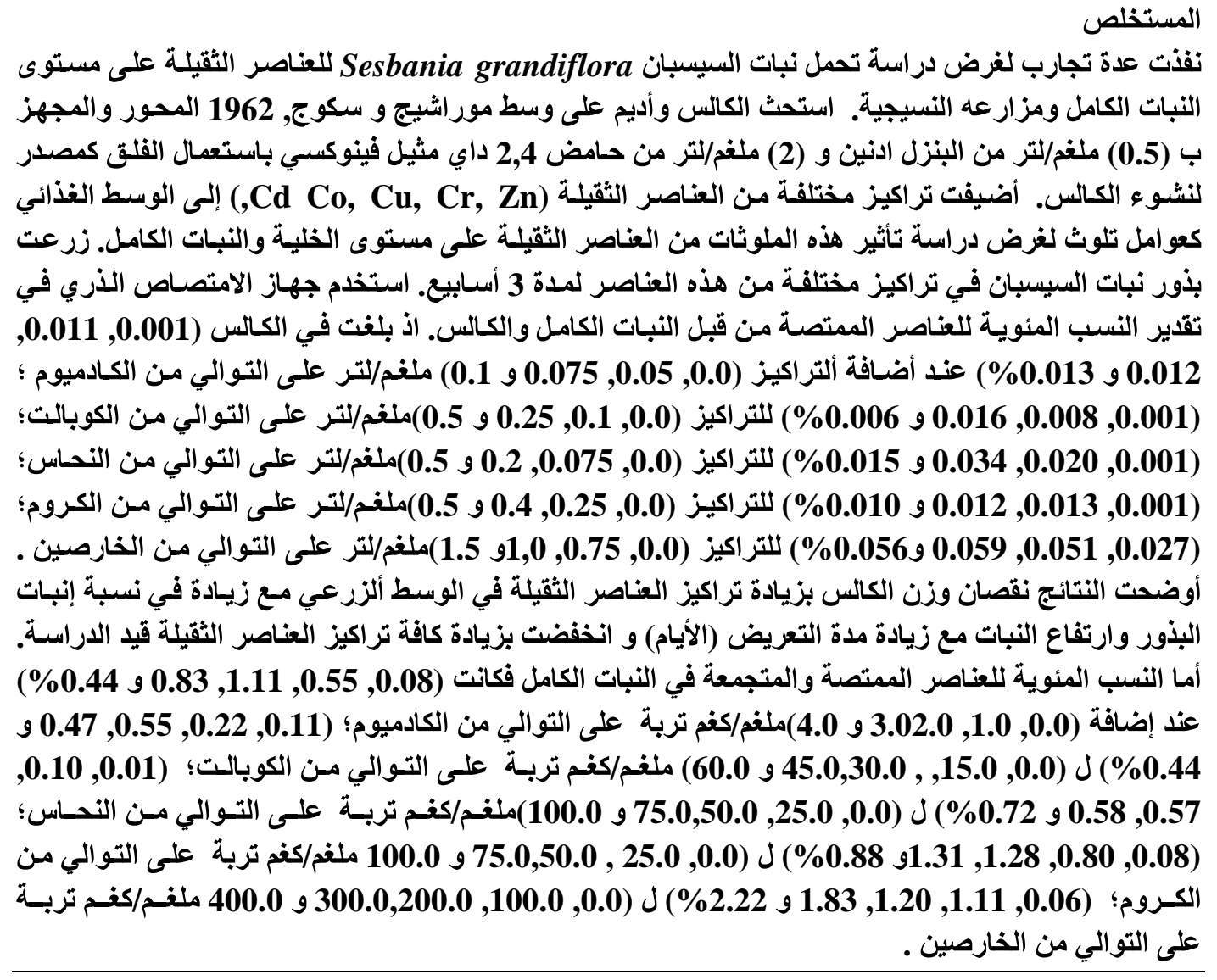

\section{Introduction}

Soils normally contain low levels of heavy metals. Excessive levels can be hazardous to man, animals and plants. The term heavy metal, however, is often broadly applied to include other potentially hazardous elements. The most important heavy metals involved in soil contamination are arsenic (As), cadmium $(\mathrm{Cd})$, chromium $(\mathrm{Cr})$, nickel $(\mathrm{Ni})$, and selenium (Se) [1].

Phytoremedation has been defined as the use of green plants and their associated microorganisms in optimized agronomical conditions to remove harmless contaminants, including organic compounds and toxic metals. Phytoremedation is a technology that aims to provide a cheap, soft and safe treatment applicable to contaminated sites". It is based on the following considerations: Short term effectiveness, reduction in the toxicity and mobility [2].

Tissue culture is a powerful tool that gives the possibility to grow millions of cells under controlled conditions, and to get physiological information about the behavior of the plant cells under stress conditions [3]. Plant tissue culture and molecular genetics have opened new avenues in plant improvement. Screening and selection at the plant cell level has established plant clones with increased tolerance or resistance in plants to various environmental stresses like salt, heat, cold, drought, disease, insects, heavy metals and herbicides [4]. Cell lines tolerant to elevated levels of salt in the medium have been selected in Brassica juncea [5]. Cell lines resistant to elevated concentrations of aluminum have been selected in Nicotiana plumbaginifolia [6]. 
The genus Sesbania belongs to the family fabaceae, which includes important plants that are used for treatment of contaminated soils. It is known for exceptionally fast growth rates as well as a very high affinity for association with nitrogen-fixing bacteria. It has several potential uses including forage, fuel wood, pulpwood, fences, medicines, shade for other crops and soil improvement [7].

The aim of this study was to asses the ability of $S$. grandiflora tissue cultures and whole plants to accumulate heavy metals in their tissues and hence using the plant for phytoremediation purposes.

\section{Materials and Methods}

Sesbania grandiflora seeds were collected from one of the fields located in Sayafia village $20 \mathrm{Km}$ south of Baghdad. MS [8] medium was used. Sucrose $30 \mathrm{~g} / \mathrm{l}$, Myoinositol $100 \mathrm{mg} / \mathrm{L}$ and the plant growth regulators 2, 4-D and BA at different concentrations were added. The $\mathrm{pH}$ of the medium was adjusted to 5.8 , and then $7 \mathrm{~g} / \mathrm{l}$ of the agar type (Agar-Agar) was added to the medium, placed on a hot plate magnetic stirrer till boiling. Aliquots of $10 \mathrm{ml}$ were dispensed into $(8 \times 2.5) \mathrm{cm}$ culture vessels. Culture media were sterilized by autoclaving at $121^{\circ} \mathrm{C}$ under $\left(1.04 \mathrm{Kg} / \mathrm{cm}^{2}\right)$ pressure, for $15 \mathrm{~min}$. Glassware and other instruments either autoclaved or placed in electric oven (180-200) ${ }^{\circ} \mathrm{C}$ for $2 \mathrm{hrs}$ [5]. The medium was left at room temperature to cool and become ready to culture explants.

S. grandiflora seeds were surface sterilized according to Purohit [9]. Briefly, they were rinsed with continuous shaking in $1.75 \% \mathrm{NaOCl}$ for 5 min., and then rinsed three times with sterilized $\mathrm{DDH}_{2} \mathrm{O}$. Seeds were submerged in $\mathrm{DDH}_{2} \mathrm{O}$ for 24 hrs, for imbibition. Embryos were dissected and discarded then cotyledons were cultured on MS medium for callus induction.

Combinations of plant growth regulators were prepared and added to the cultural medium to determine the most effective one for callus induction. Cotyledons were placed onto MS medium containing different concentrations of 2, 4-D and BA. The response of cotyledons to auxin and cytokinin combinations was evaluated after 25 days in culture. The initiated callus was removed from the explants using forceps and scalpel, then pieces weighting $35 \mathrm{mg}$ were subcultured onto fresh medium supplemented with the same combinations of 2,4-D and BA. Callus fresh weight was determined using sensitive balance, then oven dried at $60^{\circ} \mathrm{C}$ for $24 \mathrm{hrs}$ for callus dry weight measurements and for heavy metals concentration measurements. Callus pieces (35 mg each) were placed on the surface of culture medium supplemented with different concentrations of heavy metals that prepared as solutions included; $\mathrm{Cd}(0.0,0.05,0.075$ and 0.1$)$; $\mathrm{Co}$ (0.0, $0.1,0.25$ and 0.5); $\mathrm{Cu}(0.0,0.075,0.2$ and 0.5); $\mathrm{Cr}(0.0,0.25,0.4$ and 0.5) and $\mathrm{Zn}(0.0$, $0.075,0.2$ and 0.5$) \mathrm{mg} / \mathrm{l}$. The experiment was continued for 25 days. S. grandiflora seeds were germinated on different concentrations of heavy metals. These were $\mathrm{Cd}(0.0$, 1.0, 2.0, 3.0 and 4.0); Co (0.0, 15.0, 30.0, 45.0 and 60.0); $\mathrm{Cu}(0.0,25.0,50.0,75.0$ and 100.0); $\mathrm{Cr}(0.0,25.0,50.0,75.0$ and 100.0); and $\mathrm{Zn}(0.0,100.0,200.0,300.0$ and 400.0) $\mathrm{mg} / \mathrm{Kg}$ soil. This experiment was accomplished at (July-December), in pots with a diameter of $16 \mathrm{~cm}$ using clay silt soil containing: sand $140 \mathrm{~g}$, clay $640 \mathrm{~g}$, silt $220 \mathrm{~g}$. Each pot was containing $2 \mathrm{Kg}$ of soil that contaminated with heavy metals. Heavy metals were 
mixed with small amount of soil, then the contaminated soil was mixed with the bulk soil to make $2 \mathrm{Kg}$ of contaminated soil. These pots were placed under field conditions. Seeds started germination after 5 days. Germination percentage and seedling height were recorded daily for 20 days.

Samples of the plant parts were harvested (roots, stems, leaves, flowers), and subjected to analysis. Callus pieces were also harvested then dried at $60^{\circ} \mathrm{C}$ for $24 \mathrm{hrs}$ and subjected to analysis. A quantity of $0.25 \mathrm{~g}$ of the whole plant samples or callus sample was weighed and placed in the digestion apparatus, and then $10 \mathrm{ml}$ of concentrated $\mathrm{H}_{2} \mathrm{SO}_{4}$ was added and heated till boiling for $2 \mathrm{hrs}$ until the color of the sample turned black. The solution was cooled, and $1.5 \mathrm{ml}$ of $\mathrm{HClO}_{4}$ was added, reheated until the solution became clear. The volume was completed to $50 \mathrm{ml}$ using a volumetric flask. The concentrations of heavy metals in this solution were measured using Atomic Absorption Spectrophotometer [10].

\section{Results and Discussion}

Table (1) shows that the percentage of callus induction decreased with increasing of BA concentrations reaching 22.2, 100 and $66.6 \%$ in the combinations of $(2 \mathrm{mg} / 1$ 2,4-D and $0.1 \mathrm{mg} / \mathrm{l} \mathrm{BA}),(2 \mathrm{mg} / \mathrm{l} 2,4-\mathrm{D}$ and $0.5 \mathrm{mg} / \mathrm{l} \mathrm{BA}),(2 \mathrm{mg} / \mathrm{l} 2,4-\mathrm{D}$ and $1.0 \mathrm{mg} / \mathrm{l} \mathrm{BA})$ respectively. These percentages fluctuated with increasing 2,4-D concentrations which were $(33.3,55.5,33.3$ and 22.2$) \%$ for combination of $(2.5 \mathrm{mg} / \mathrm{l} 2,4-\mathrm{D}$ and $0.1 \mathrm{mg} / \mathrm{l} \mathrm{BA})$, (2.5mg/l 2,4-D and 0.5mg/l BA), (2.5mg/1 2,4-D and 1.0mg/l BA), (2.5mg/1 2,4-D and $1.5 \mathrm{mg} / \mathrm{l} \mathrm{BA})$ respectively. No callus induction was reported on untreated cotyledon explants, and in the interaction between low concentrations of 2, 4-D and BA.

Table (1): Percentages of $S$. grandiflora explants showed callus initiation on MS medium supplemented with different concentrations of 2,4-D and BA after 25 days $(n=9)$

\begin{tabular}{|c|c|c|c|c|c|}
\hline \multirow{2}{*}{$\begin{array}{c}\mathbf{2 , 4 - D} \\
(\mathbf{m g} / \mathbf{l})\end{array}$} & $\mathbf{0 . 0}$ & $\mathbf{0 . 1}$ & $\mathbf{0 . 5}$ & $\mathbf{1 . 0}$ & $\mathbf{1 . 5}$ \\
\hline 0.0 & $*$ & $*$ & $*$ & $*$ & $*$ \\
\hline 0.5 & $*$ & $*$ & $*$ & $*$ & $*$ \\
\hline 1.0 & $*$ & $*$ & $*$ & $*$ & $*$ \\
\hline 2.0 & $*$ & 22.2 & 100 & 66.6 & 22.2 \\
\hline 2.5 & $*$ & 33.3 & 55.5 & 33.3 & 22.2 \\
\hline
\end{tabular}

(*) No callus induction occurred

Calli were inoculated into the same combinations of plant growth regulators used for callus induction to determine the appropriate one for callus maintenance (Table 2). The combination of $2.0 \mathrm{mg} / \mathrm{l} 2,4-\mathrm{D}$ and $0.5 \mathrm{mg} / \mathrm{l}$ BA produced more callus fresh weight $(615.57 \mathrm{mg}$ ) than any other ones (fig. 1). Dry weight of callus cultures initiated from cotyledon explants on MS medium is shown in Table (3). Maximum dry weight occurred in the combination of 2.0mg/1 2, 4-D and 0.5mg/l BA (190.10mg). Lower dry weight recorded as $(100.01,111.01,95.81$ and 60.10) $\mathrm{mg}$ in combinations of $(0.1 \mathrm{mg} / \mathrm{l}$ 
BA and 2.5mg/1 2, 4-D), (0.5mg/1 BA and 2.5mg/l 2,4-D), (1.0mg/l of BA and 2.5mg/l of $2,4-\mathrm{D})$ and $(1.5 \mathrm{mg} / \mathrm{l} \mathrm{BA}$ and $2.5 \mathrm{mg} / 12,4-\mathrm{D})$ respectively.

The effect of different concentrations of $\mathrm{Cd}$ on callus fresh weight was determined as shown in (fig. 2). There was a progressive decline in callus fresh weight with increasing $\mathrm{Cd}$ concentration. Cadmium is a non essential element that negatively affects plant growth and development. It is relatively mobile in plants since it influences mineral nutrition [11]. According to the results stated above, callus was induced on cotyledon explants then maintained for many subcultures on MS medium containing $0.5 \mathrm{mg} / \mathrm{BA}$ and 2mg/1 2,4-D for subsequent experiments

Table (2): Callus fresh weight (mg) grown on MS medium supplemented with different combinations of 2,4-D and BA, after 25 days, the initial callus fresh weight is $35 \mathrm{mg}(\mathbf{n}=9)$

\begin{tabular}{|c|c|c|c|c|c|}
\hline \multirow{2}{*}{$\begin{array}{c}\text { 2,4-D } \\
(\mathbf{m g} / \mathbf{l})\end{array}$} & $\mathbf{0 . 0}$ & $\mathbf{0 . 1}$ & $\mathbf{0 . 5}$ & $\mathbf{1 . 0}$ & $\mathbf{1 . 5}$ \\
\cline { 2 - 6 } & $*$ & $*$ & $*$ & $*$ & $*$ \\
\hline 0.5 & $*$ & $*$ & $*$ & $*$ & $*$ \\
\hline 1.0 & $*$ & $*$ & $*$ & $*$ & $*$ \\
\hline 2.0 & $*$ & 190.01 & 615.57 & 522.05 & 200.95 \\
\hline 2.5 & $*$ & 241.01 & 443.50 & 211.91 & 197.21 \\
\hline
\end{tabular}

(*) Callus showed significant deterioration

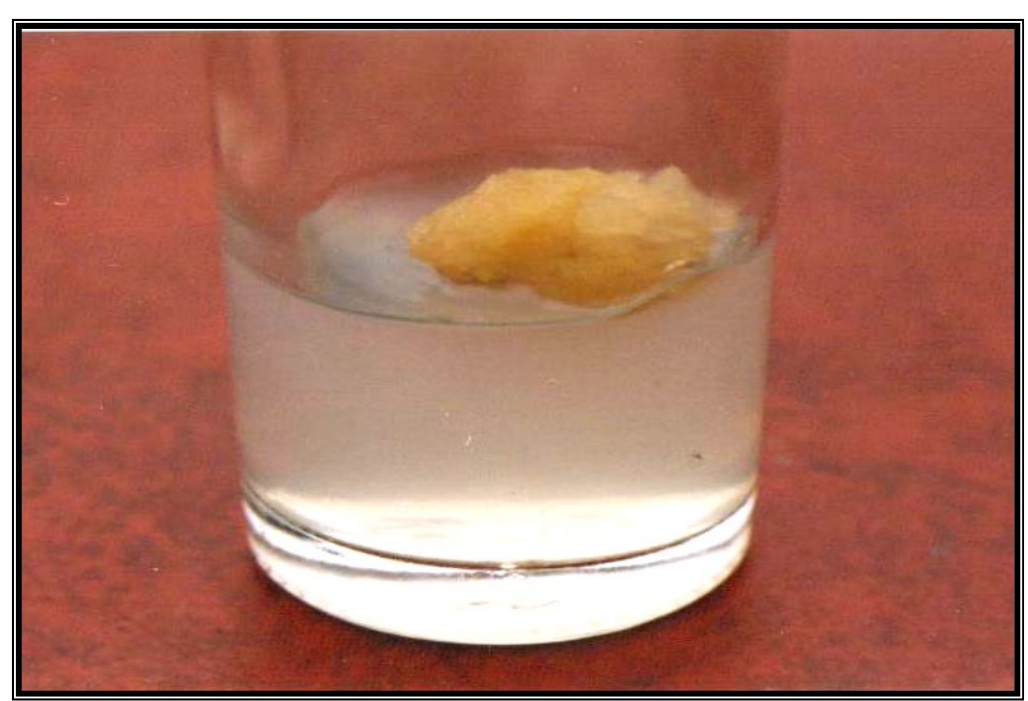

Fig (1): Callus grown on MS medium supplemented with 2.0mg/l 2, 4-D and 0.5mg/l BA, after 25 days in culture

Induction and maintenance of callus cultures in S. grandiflora seems to favor high levels of 2,4-D and lower level of BA. Auxin is generally included in a culture medium to stimulate cell growth, induction of somatic embryogenesis and stimulate growth of shoot apices, shoot tip cultures and cotyledons [9]. Cytokinin is very important for cell division in the presence of the auxin. So, the interaction between the cytokinin and the 
auxin led to cell division and callus induction. It is also prevents the oxidation of the natural auxin IAA [12].

Fig. (3) Represents the effect of different concentrations of Co on callus fresh weight. The highest callus fresh weight obtained in control treatment reached up to (58.6) $\mathrm{mg}$, then started to decrease with increasing Co concentration reaching (43.7, 41 and 38.2) $\mathrm{mg}$ for the media containing $(0.10,0.25$ or 0.50$) \mathrm{mg} / \mathrm{l} \mathrm{Co.}$

Table (3): Callus dry weight (mg) grown on MS medium supplemented with different concentrations of 2,4-D and BA for 25 days $(n=9)$

\begin{tabular}{|c|c|c|c|c|c|}
\hline \multirow{2}{*}{$\begin{array}{c}\mathbf{2 , 4 - D} \\
(\mathbf{m g} / \mathbf{l})\end{array}$} & $\mathbf{0 . 0}$ & $\mathbf{0 . 1}$ & $\mathbf{0 . 5}$ & $\mathbf{1 . 0}$ & $\mathbf{1 . 5}$ \\
\cline { 2 - 6 } & $*$ & $*$ & $*$ & $*$ & $*$ \\
\hline 0.0 & $*$ & $*$ & $*$ & $*$ & $*$ \\
\hline 0.5 & $*$ & $*$ & $*$ & $*$ & $*$ \\
\hline 1.0 & $*$ & 52.59 & 190.10 & 145.52 & 89.05 \\
\hline 2.0 & $*$ & 100.01 & 111.01 & 95.81 & 60.10 \\
\hline 2.5 & & & &
\end{tabular}

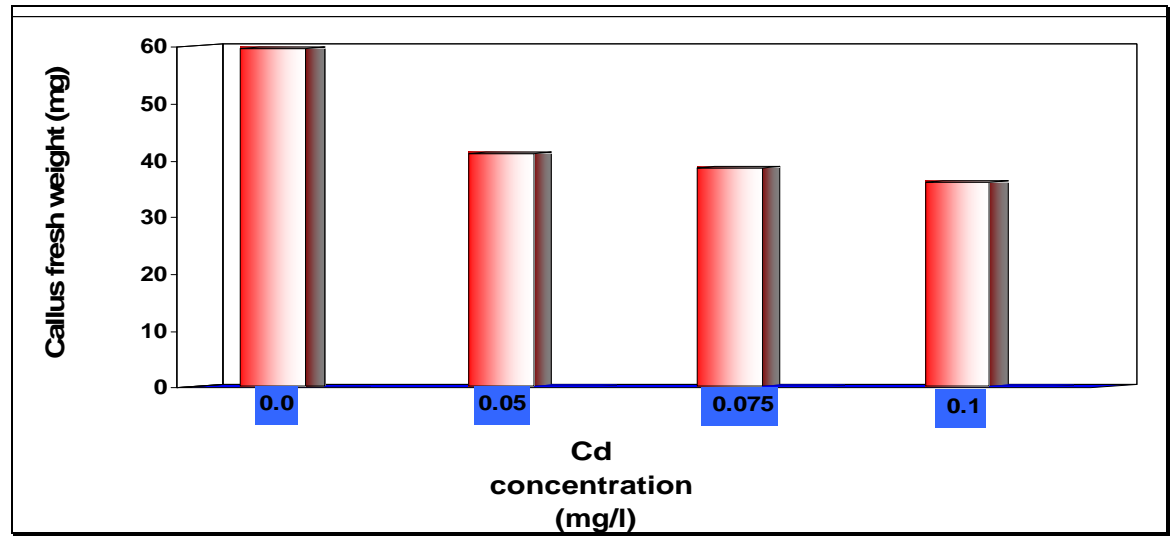

Fig (2): Effect of different concentrations of Cadmium on callus fresh weight grown on MS medium supplemented with $0.5 \mathrm{mg} / \mathrm{l} \mathrm{BA}$ and $2 \mathrm{mg} / \mathrm{l} 2,4-\mathrm{D}$, after 25 days. The initial callus fresh weight is $35 \mathrm{mg}(\mathrm{n}=9)$ 


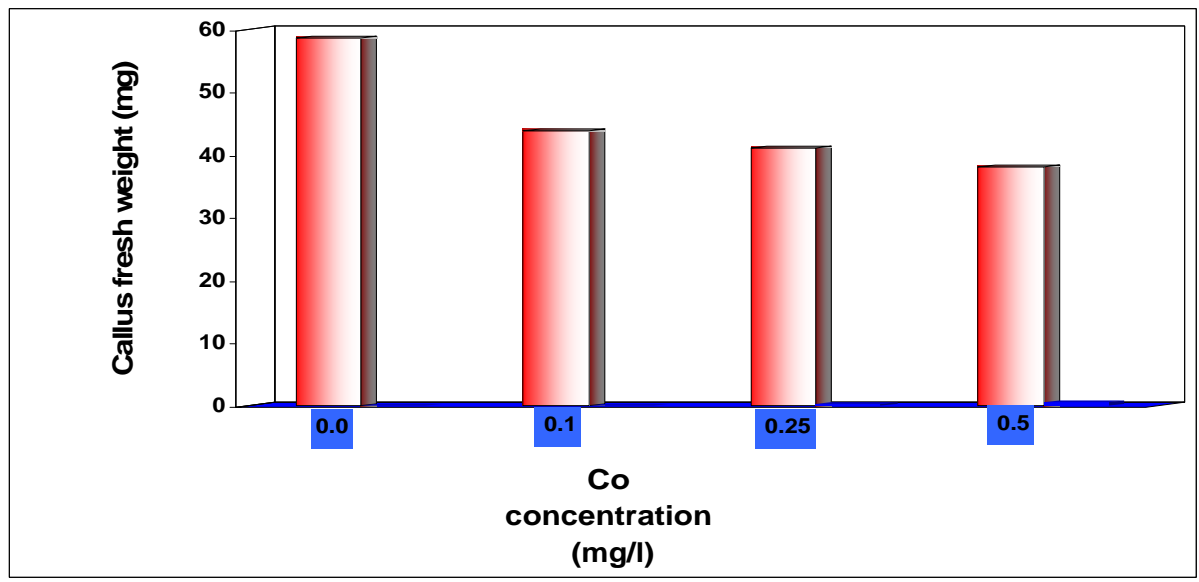

Fig (3): Effect of different concentrations of Cobalt on callus fresh weight grown on MS medium supplemented with $0.5 \mathrm{mg} / \mathrm{l} \mathrm{BA}$ and $2 \mathrm{mg} / \mathrm{l} 2,4-\mathrm{D}$, after 25 days. The initial callus fresh weight is $35 \mathrm{mg}(\mathrm{n}=9)$

Cobalt is considered as transition element, plays an important role in plants as cofactor absorbed from soil or media by tissues or plants [13]. Callus fresh weight decreased with increasing of $\mathrm{Cu}$ concentration (fig. 4). Maximum callus fresh weight was reported in (0.0) $\mathrm{mg} / \mathrm{l} \mathrm{Cu}$ reached (62.4) $\mathrm{mg}$ then decreased at (0.075 and 0.2) $\mathrm{mg} / \mathrm{l}$ of $\mathrm{Cu}$ recording (56.8 and 51.1) $\mathrm{mg}$ respectively. While the lowest callus fresh weight was recorded in (0.5) $\mathrm{mg} / \mathrm{l} \mathrm{Cu}$ reached (40) mg. Copper is essential for plant growth and development, since it interacts with many enzymes and proteins. While elevated concentrations of $\mathrm{Cu}$ leads to toxicity symptoms and inhibition of plant growth [14].

The highest callus fresh weight recorded was (62) $\mathrm{mg}$ in callus cultures grown on $\mathrm{Cr}$ free medium. Meanwhile callus fresh weight decreased at $(0.25,0.40$ and 0.5$) \mathrm{mg} / \mathrm{l}$ of $\mathrm{Cr}$ reached (57.1, 49.2 and 42.5) respectively fig. (5).

Fig.(6) exhibits that the highest callus fresh weight (61)mg appeared in control treatment. A decline in callus fresh weight with increasing $\mathrm{Zn}$ concentration reached $(51.5,46.1$ and 39.2) $\mathrm{mg}$ for $(0.75,1.00$ and 1.50) $\mathrm{mg} / \mathrm{l}$ of $\mathrm{Zn}$ respectively. High levels of $\mathrm{Zn}$ lead to toxicity symptoms and inhibition of plant growth. Toxicity led to an inhibition of cell activity or disruption of its structure. In addition, excess $\mathrm{Zn}$ may stimulate the formation of free radicals, perhaps resulting in oxidative stress [15]. 


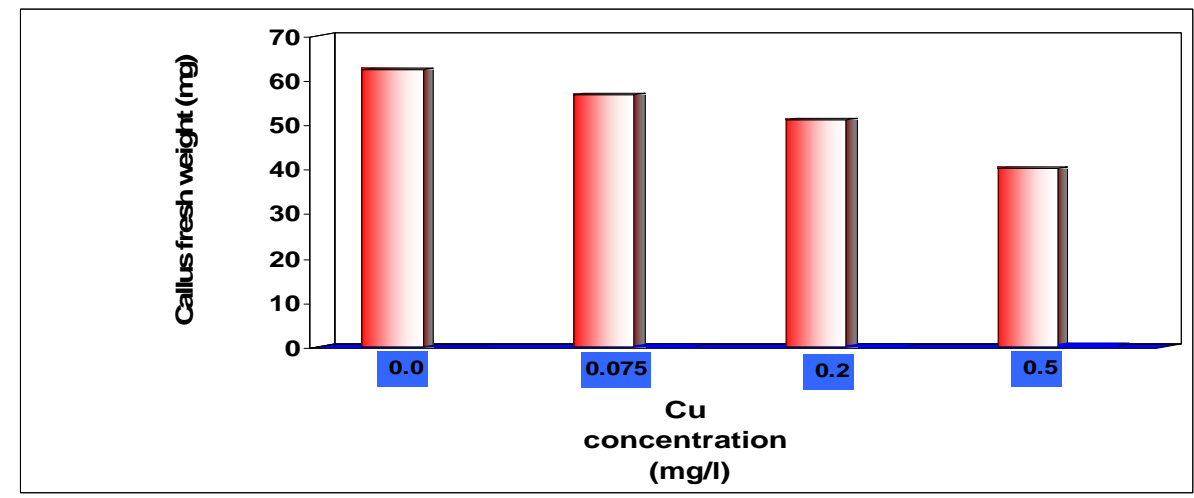

Fig (4): Effect of different concentrations of Copper on callus fresh weight grown on MS medium supplemented with $0.5 \mathrm{mg} / \mathrm{BA}$ and $2 \mathrm{mg} / \mathrm{l} 2$, 4-D, after 25 days. The initial callus fresh weight is $35 \mathrm{mg}(\mathrm{n}=9)$

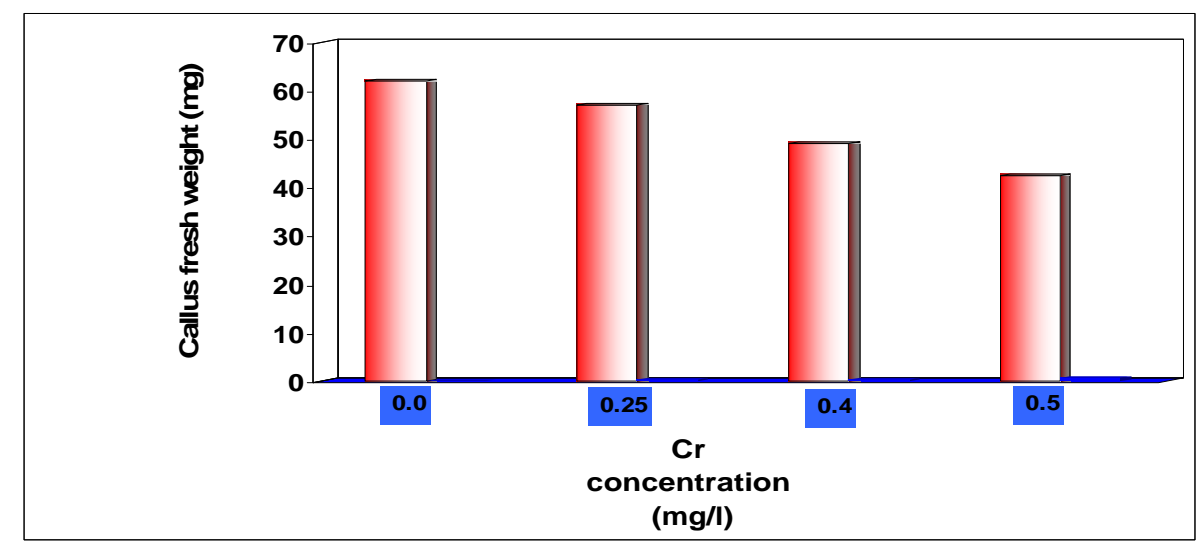

Fig (5): Effect of different concentrations of Chromium on callus fresh weight grown on MS medium supplemented with $0.5 \mathrm{mg} / \mathrm{BA}$ and $2 \mathrm{mg} / 1$ 2, 4-D, after 25 days. The initial callus fresh weight is $35 \mathrm{mg}(\mathrm{n}=9)$

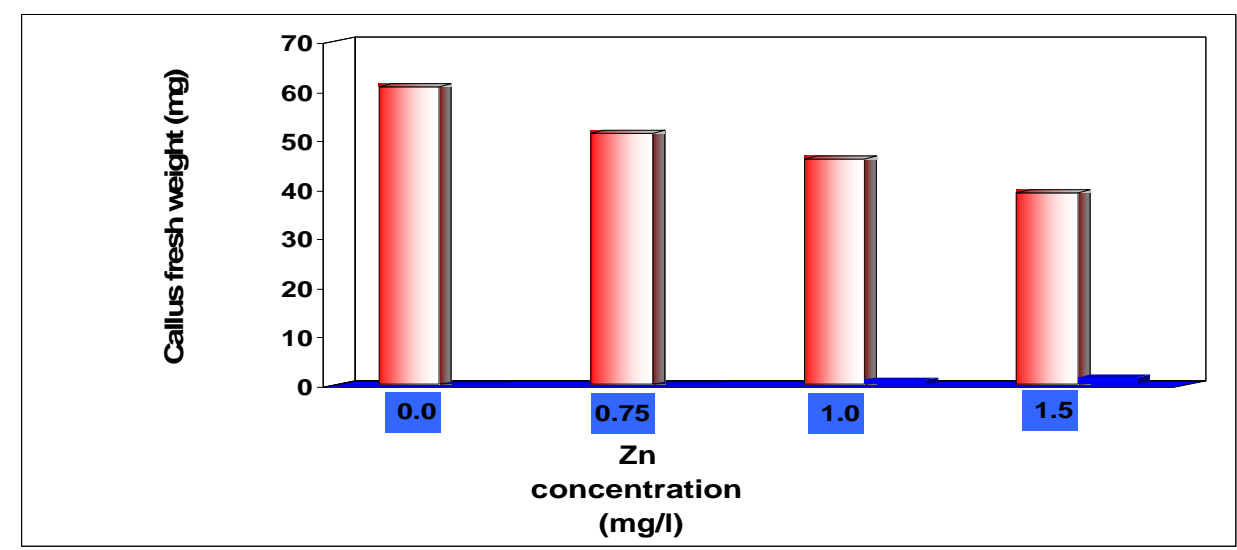

Fig (6): Effect of different concentrations of Zinc on callus fresh weight grown on MS medium supplemented with $0.5 \mathrm{mg} / \mathrm{BA}$ and $2 \mathrm{mg} / 1$ 2, 4-D, after 25 days. The initial callus fresh is $35 \mathrm{mg}(\mathrm{n}=9)$

The concentration of $\mathrm{Cd}$ accumulated in callus cultures increased with increasing of $\mathrm{Cd}$ concentration (Table 4). This is in agreement with Duxbury, (1985) [16] who classified 
$\mathrm{Cd}$ as an element of intermediate toxicity. While the concentrations of heavy metals absorbed by callus increased by increasing of heavy metals concentrations reaching $(0.25,0.2,0.25$ and 1.0$) \mathrm{mg} / \mathrm{l}$ of $(\mathrm{Co}, \mathrm{Cu}, \mathrm{Cr}$ and $\mathrm{Zn})$ respectively.

Table (4): Concentrations of heavy metal ions absorbed by callus culture of $S$. grandiflora grown on MS medium supplemented with 2mg/l 2,4-D and $0.5 \mathrm{mg} / \mathrm{l} \mathrm{BA}$, after 25 days

\begin{tabular}{|c|c|c|}
\hline Treatmen & $\begin{array}{c}\text { Heavy metal } \\
\text { concentration }(\mathrm{mg} / \mathrm{l})\end{array}$ & $\begin{array}{c}\text { Absorbed concentration } \\
(\mathbf{p p m})\end{array}$ \\
\hline Control & 0.0 & 2 \\
\hline \multirow{3}{*}{$\mathrm{Cd}$} & 0.05 & 110 \\
\hline & 0.075 & 120 \\
\hline & 0.10 & 130 \\
\hline Control & 0.0 & 10 \\
\hline \multirow{3}{*}{$\mathrm{Co}$} & 0.1 & 80 \\
\hline & 0.25 & 160 \\
\hline & 0.5 & 60 \\
\hline Control & 0.0 & 100 \\
\hline \multirow{3}{*}{$\mathrm{Cu}$} & 0.075 & 200 \\
\hline & 0.25 & 340 \\
\hline & 0.50 & 150 \\
\hline Control & 0.0 & 1.5 \\
\hline \multirow{3}{*}{$\mathrm{Cr}$} & 0.25 & 130 \\
\hline & 0.4 & 120 \\
\hline & 0.5 & 100 \\
\hline Control & 0.0 & 150 \\
\hline \multirow{3}{*}{$\mathrm{Zn}$} & 0.75 & 450 \\
\hline & 1.0 & 560 \\
\hline & 1.5 & 340 \\
\hline
\end{tabular}

This amount decreased $(0.5,0.5,0.4$ and 1.5)mg/l with increasing $\mathrm{Co}, \mathrm{Cu}, \mathrm{Cr}$ and $\mathrm{Zn}$ concentrations respectively. This result is in agreement with Benavides et al., (2005)[17] who found that Cobalt, Copper, Chromium, Zinc, and Nickel are toxic elements to plant tissue at high concentrations. In order to calculate the germination percentage of germinated seeds subjected to heavy metals under field conditions. Germination started at day 6 in all treatments reaching to $(87.1 \%)$ in control.

Germination declined with increasing Cd level over time course. At the end of day 20, germination percentages reached to $(99.7,92.6,84,70.6$ and $52 \%$ ) for the $\mathrm{Cd}$ concentrations $(0,1,2,3$ and 4$) \mathrm{mg} / \mathrm{Kg}$ soil respectively fig. (7). 


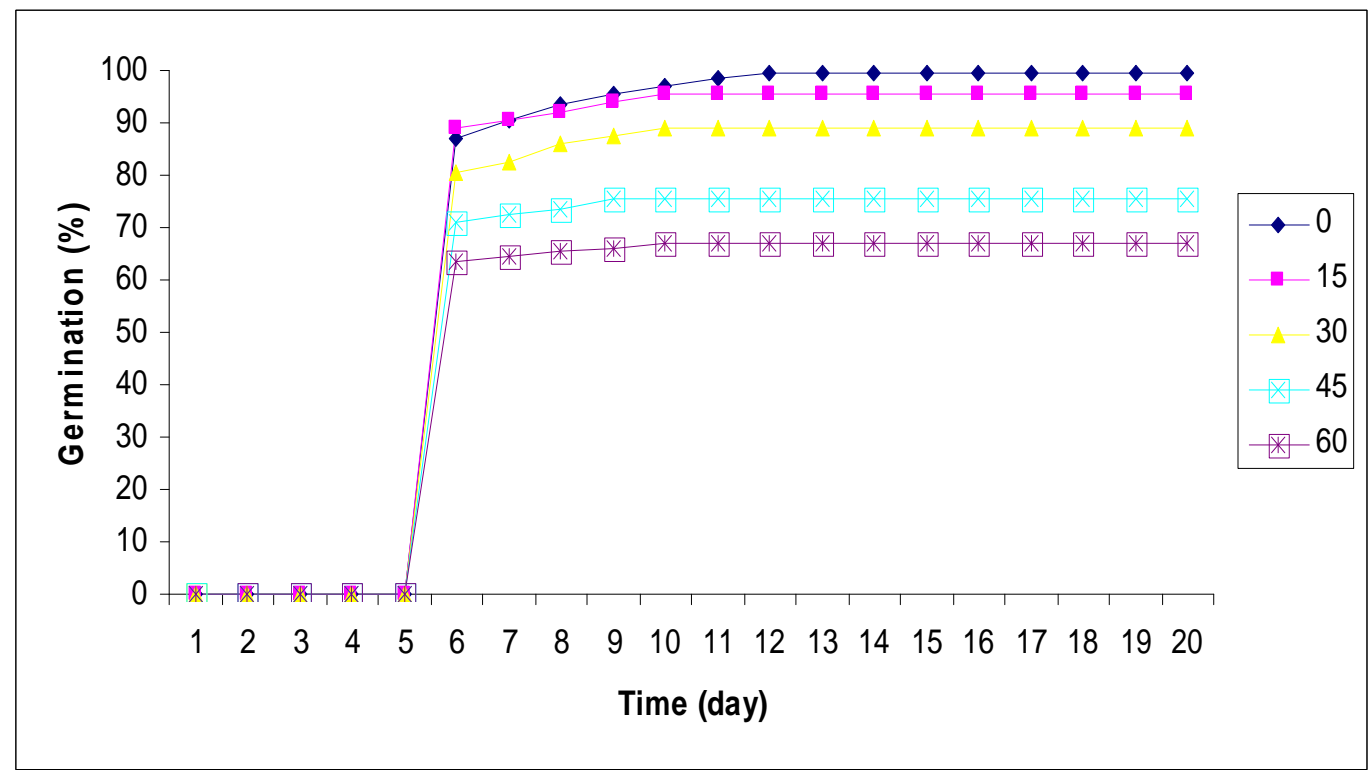

Fig (7): Germination percentages of $S$. grandiflora seeds germinated for 20 days on different concentrations of $\mathrm{Cd}(\mathrm{mg} / \mathrm{Kg}$ soil)

Maximum plant height was recorded in control at the end of day 20 reached $32.6 \mathrm{~cm}$ fig. (8). Plant height decreased with increasing Cd concentration recording (25, 20.6, 16.6 and 11.6$) \mathrm{cm}$ at $(1,2,3$ and 4$) \mathrm{mg} / \mathrm{Kg}$ soil respectively. $\mathrm{Cd}$ is considered as a heavy metal or metal trace element frequently applied to agricultural land as a fertilizer [1]. High amounts of $\mathrm{Cd}$ in plants lead to damage the photosynthetic apparatus, inhibition of Rubisco activity in Calvin cycle, decreased seed germination, affection of photosystems I and II. The levels of total chlorophyll and carotenoids are reduced [18].

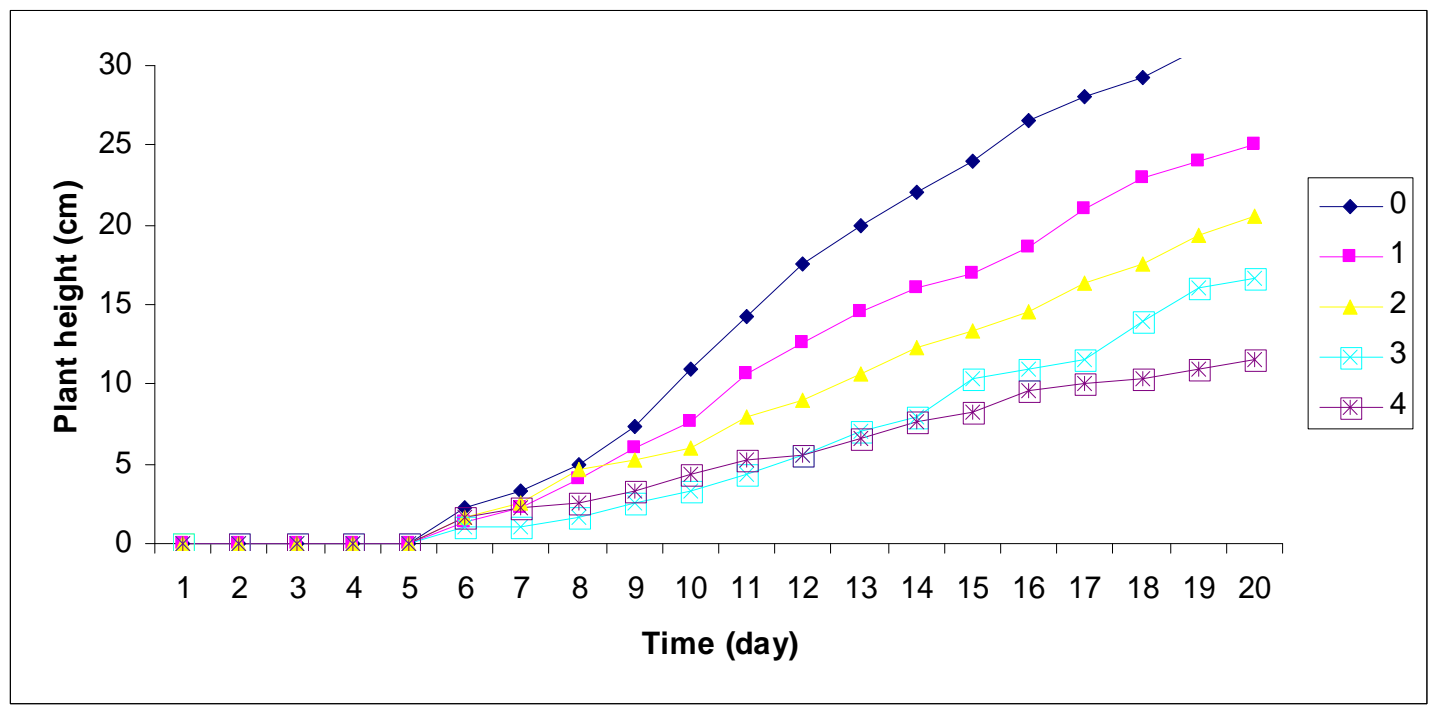

Fig (8): Effect of different concentrations of $\mathrm{Cd}(\mathrm{mg} / \mathrm{Kg}$ soil) on plant height after 20 days growth in pots

Fig. (9) shows that the highest germination percentage of germinated seeds was $99.7 \%$ recorded in control treatment at day 20. Germination percentages decreased with 
increasing Co concentration reaching $(95.4,89,75.6$ and $67 \%)$ at Co concentrations $(15$, $30,45$ and 60$) \mathrm{mg} / \mathrm{Kg}$ soil respectively.

Cobalt is a kind of trace element and heavy metal found in soil that can be incorporated into the active site of urease and render enzyme inactive. Excess Co induces yield reduction and an inhibition in assimilates production in leaves, and even inhibits the export of photo assimilates to roots and causes toxicity to plants [19].

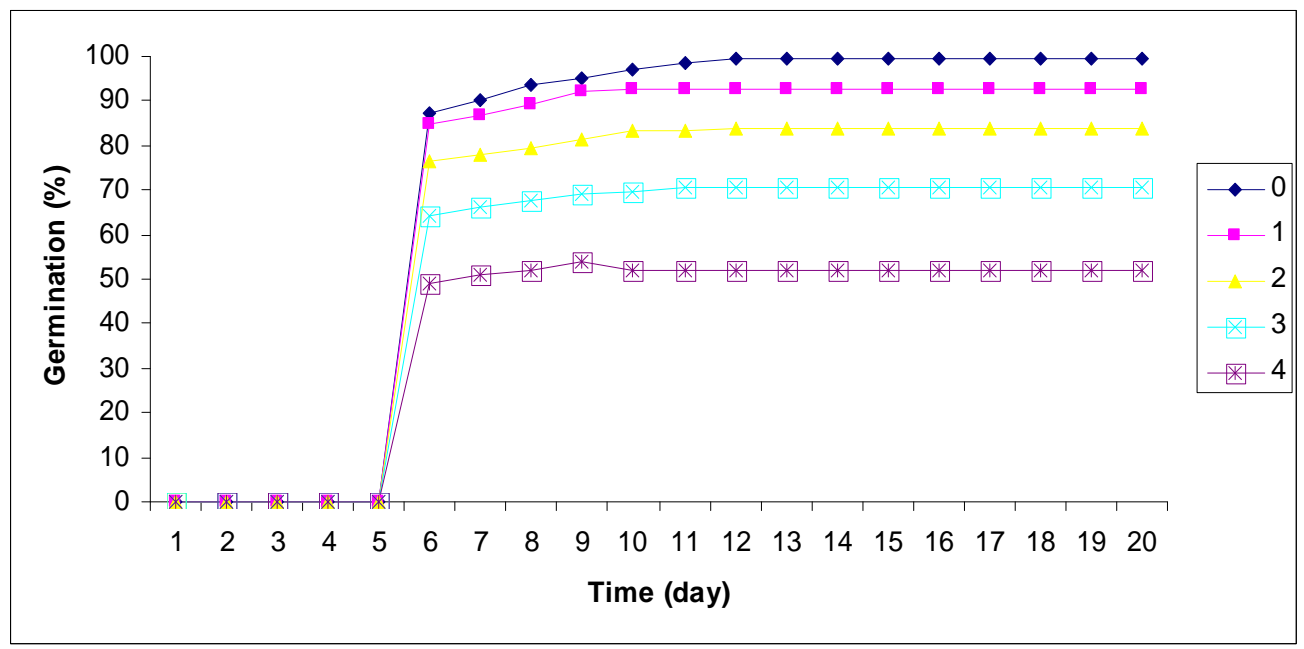

Figure (9): Germination percentages of $S$. grandiflora seeds germinated for 20 days on different concentrations of $\mathrm{Co}(\mathrm{mg} / \mathrm{Kg}$ soil)

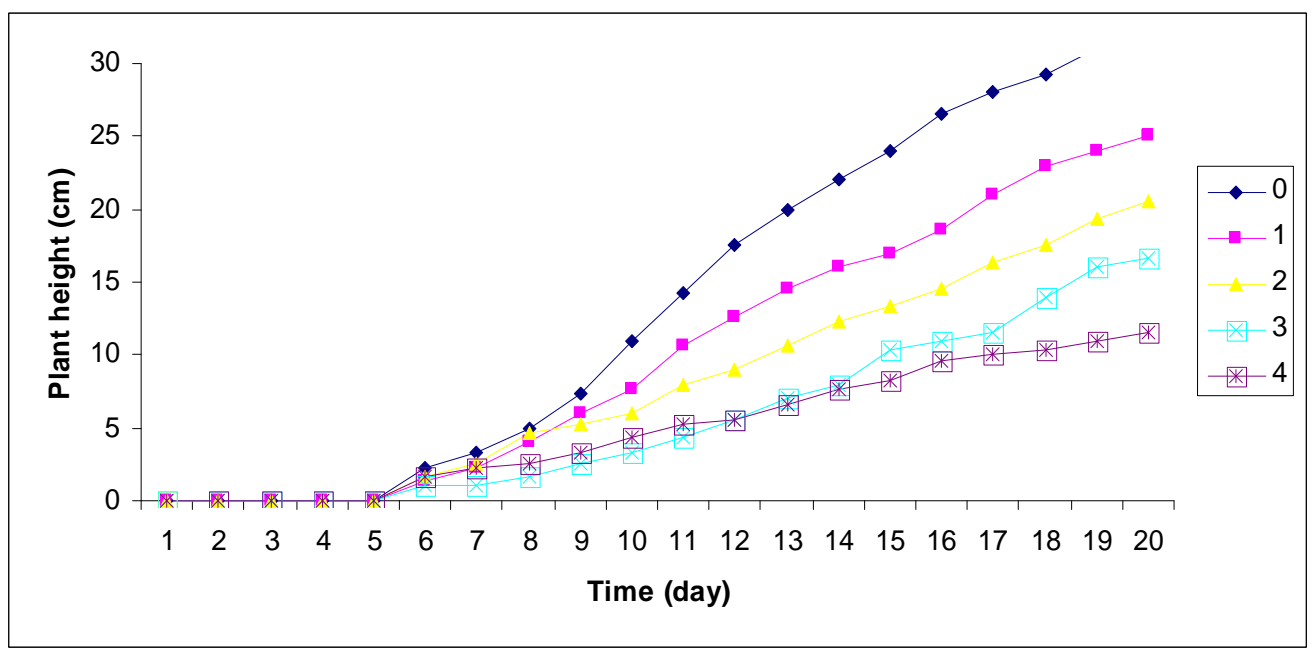

Fig (10): Effect of different concentrations of $\mathrm{Co}(\mathrm{mg} / \mathrm{Kg}$ soil) on plant height after 20 days growth in pots

Germination percentages decreased with increasing $\mathrm{Cu}$ concentrations fig. (11). the highest germination percentage was recorded in control $(99.7 \%)$. The germination percentages decreased at $(25,50,75$ and 100$) \mathrm{mg} / \mathrm{Kg}$ soil of $\mathrm{Cu}$ reaching $(89,84.6,77.6$ and $71.6 \%$ ) respectively. Fig. (12) Shows that plant height decreased with increasing $\mathrm{Cu}$ concentration and time. Maximum plant height was (32.6) $\mathrm{cm}$ recorded in control then decreased at $(25,50,75$ and 100) $\mathrm{mg} / \mathrm{Kg}$ soil reaching $(27.6,25,21.6$ and 18) $\mathrm{cm}$ 
respectively. $\mathrm{Cu}$ is essential plant micronutrients. High levels of $\mathrm{Cu}$ are toxic to plants because of binding to soil organic matter and become unavailable to plant [1].

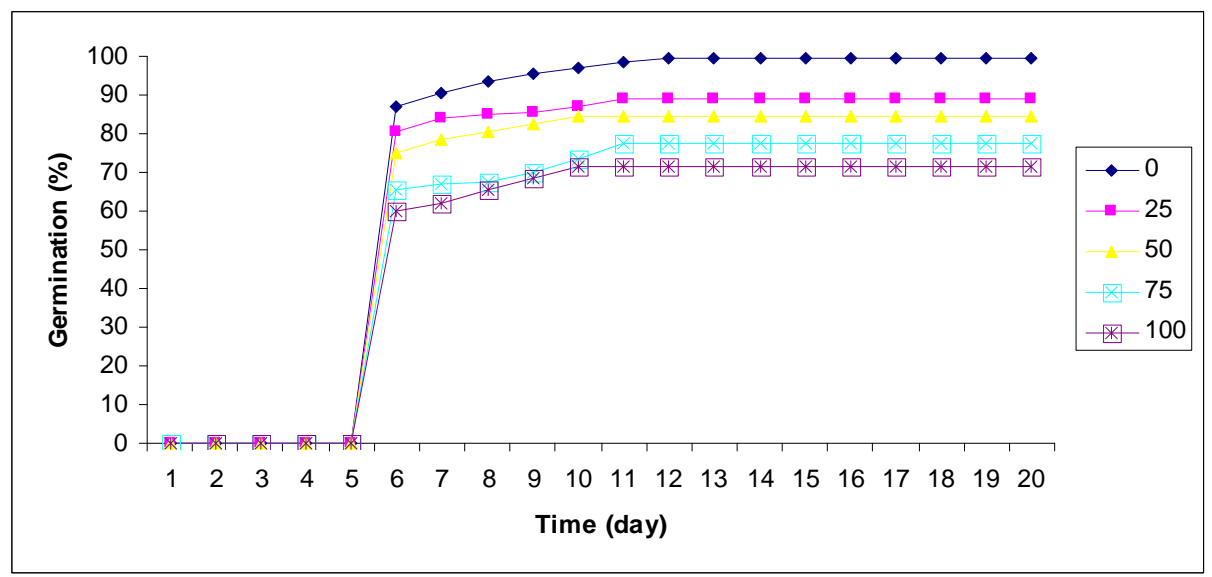

Fig (11): Germination percentages of $S$. grandiflora seeds germinated for 20 days on different concentrations of $\mathrm{Cu}(\mathrm{mg} / \mathrm{Kg}$ soil)

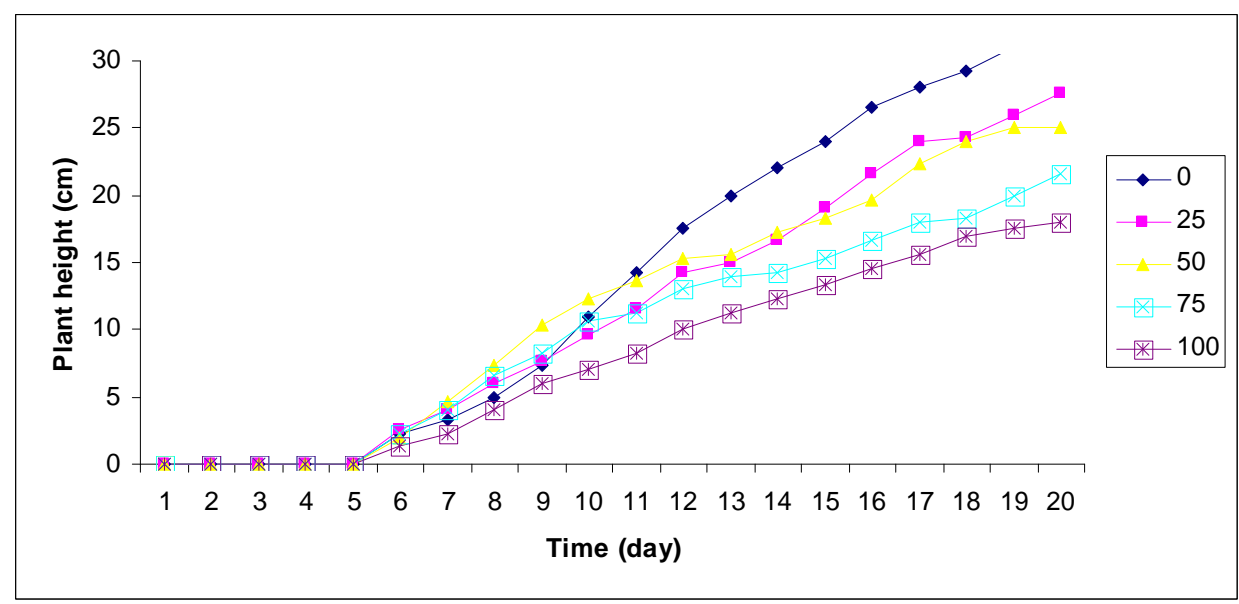

Fig (12): Effect of different concentrations of $\mathrm{Cu}(\mathrm{mg} / \mathrm{Kg}$ soil) on plant height after 20 days growth in pots

Germination percentages of seeds exposed to different $\mathrm{Cr}$ concentration are shown in fig.(13). Germination started at day 6. Maximum germination percentage was recorded in control treatment reaching $(99.7 \%)$, then declined at $(25,50,75$ and 100$) \mathrm{mg} / \mathrm{Kg}$ soil reaching $(80,78.5,74.1$ and 63.5$) \%$ respectively at day 20 .

Fig. (14) Shows that the plant height increased gradually recording maximum height in control (32.6) $\mathrm{cm}$. While the lowest plant height recorded (10) $\mathrm{cm}$ at (100) $\mathrm{mg} / \mathrm{Kg}$ soil. Chromium is a naturally occurring element found in rocks, animals, plants and soil. It is present in the environment in several different forms. The most common form is chromium (III) occurs naturally in the environment and is an essential nutrient, but high amounts of $\mathrm{Cr}$ lead to toxicity in plant, animals and human. 


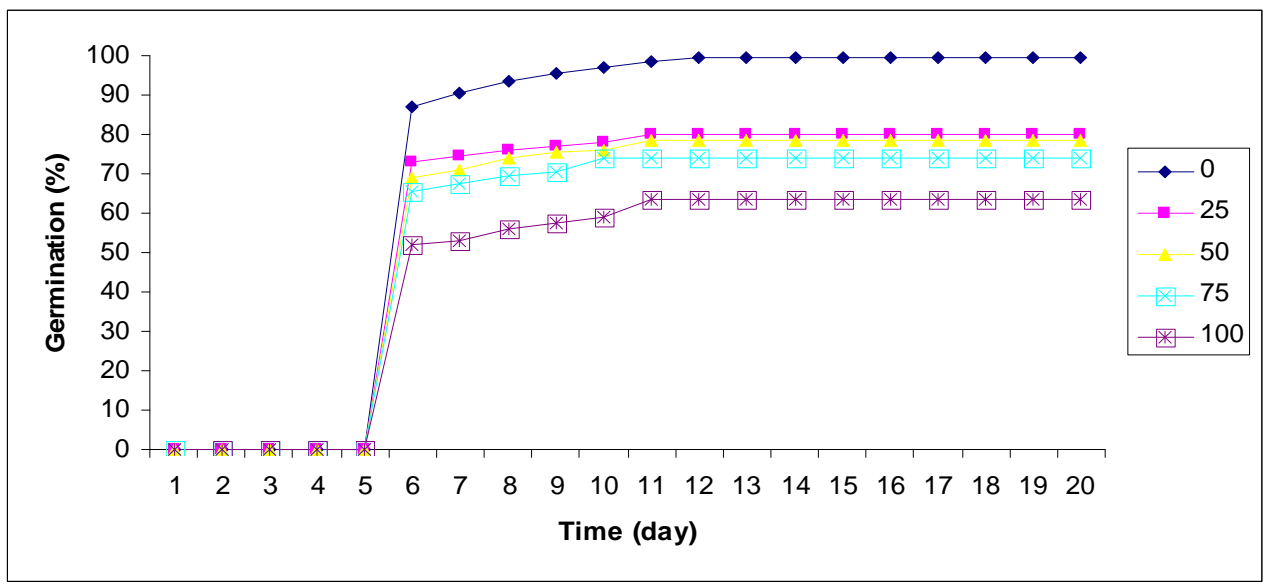

Fig (13): Germination percentages of $S$. grandiflora seeds germinated for 20 days on different concentrations of $\mathrm{Cr}(\mathrm{mg} / \mathrm{Kg}$ soil)

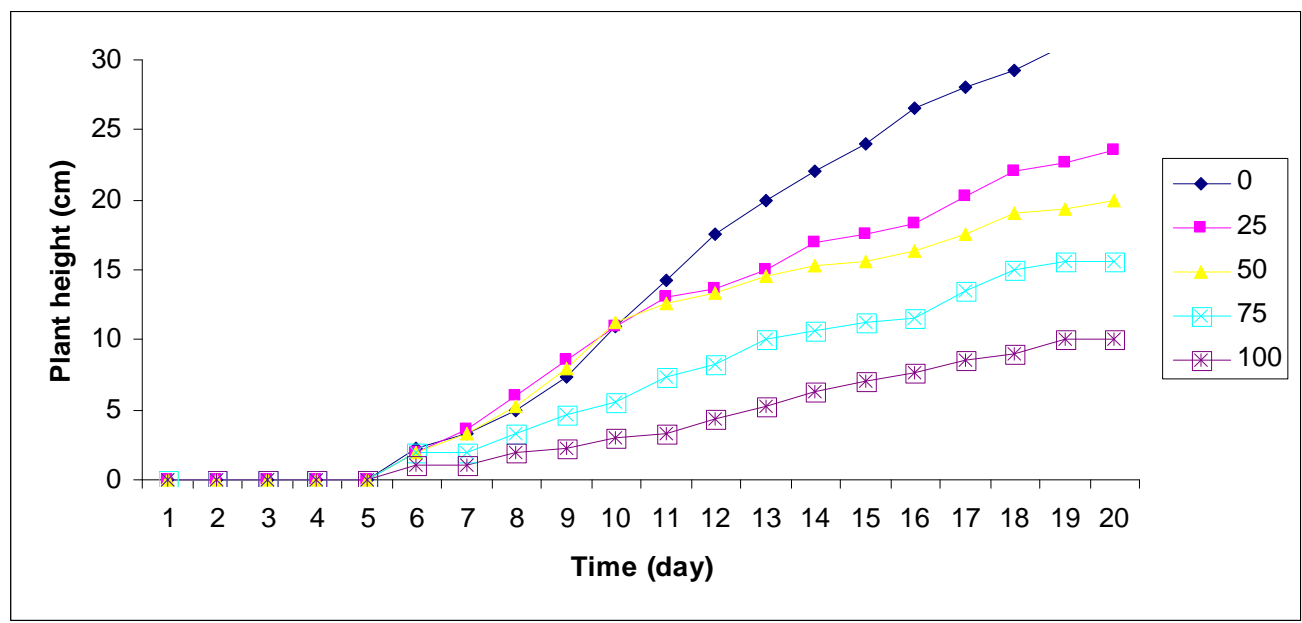

Fig (14): Effect of different concentrations of $\mathrm{Cr}$ (mg/Kg soil) on plant height after 20 days growth in pots

Treatment with $\mathrm{Zn}$ fig. (15) Resulted in a decline in seed germination. Maximum germination percentage was recorded in control treatment reaching (99.7\%). While reached to a minimum $(38.4 \%)$ at (400) $\mathrm{mg} \mathrm{Zn} / \mathrm{Kg}$ soil. These percentages increased with decreasing $\mathrm{Zn}$ concentration reaching (50.6, 59.2 and 67.4\%) at (300, 200 and 100) $\mathrm{mg} / \mathrm{Kg}$ soil respectively.

Plant height increased over time reaching (32.6) $\mathrm{cm}$ in control treatment at day 20 (fig. 16), then decreased with increasing $\mathrm{Zn}$ concentration reaching (26, 21.5, 18.5 and $13.5) \mathrm{cm}$ at $(100,200,300$ and 400$) \mathrm{mg} / \mathrm{Kg}$ soil respectively. Zinc is an essential element for both plants and animals. It plays an important role in several plant metabolic processes, it activates enzymes and is involved in protein synthesis, carbohydrates, nucleic acids and lipids metabolism. Excessive accumulation in plant tissues causes alterations in vital growth processes such as photosynthesis and chlorophyll biosynthesis [20]. 


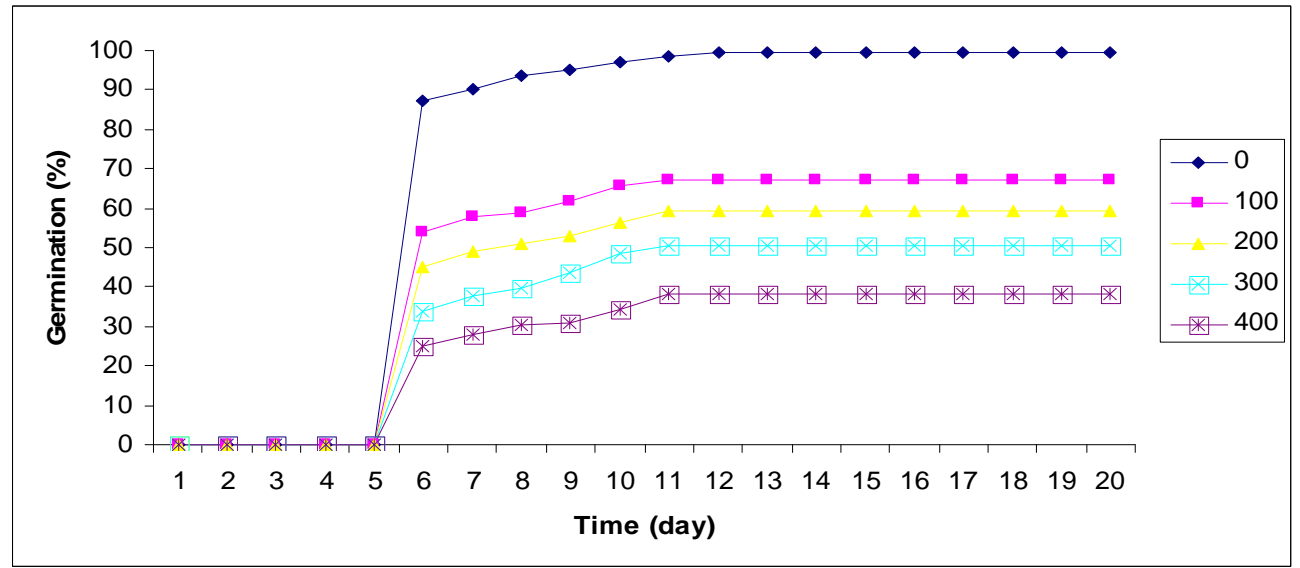

Fig (15): Germination percentages of $S$. grandiflora seeds germinated for 20 days on different concentrations of $\mathrm{Zn}$ ( $\mathrm{mg} / \mathrm{Kg}$ soil)

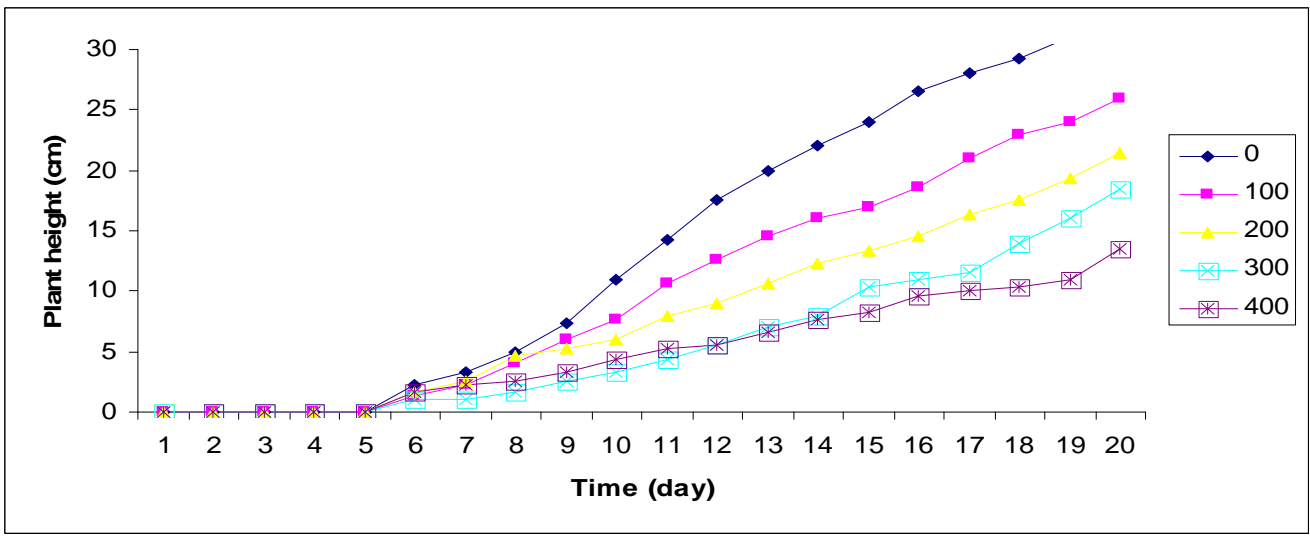

Fig (16): Effect of different concentrations of $\mathrm{Zn}(\mathrm{mg} / \mathrm{Kg}$ soil) on plant height after 20 days growth in pots

There are two mechanisms responsible for metal transport from soil particles to plant roots: mass flow, and diffusion, that make the soluble ions move from soil to root surfaces as sediments in tissues and therefore prevent growth [21].

Plants evolved several effective mechanisms for tolerating high concentrations of heavy metals. Because of their charge, metal ion can not move freely across the cellular membranes, which are lipophilic structures. Therefore, ion transport into cells must be mediated by membrane proteins with transport functions, known as transporters. Transmembrane transporters possess an extra cellular binding domain to which the ion attach just before the transport, and a transmembrane structure which connects extra cellular media. The binding domain is receptive only to specific ions and is responsible for transporter specificity. The transmembrane structure facilitates the transfer of bound ions from extra cellular space through the hydrophobic environment of the membrane into the cell [22]. As shown in table (5) the highest concentration of Cd accumulated was measured at (2) $\mathrm{mg} / \mathrm{Kg}$ soil reaching (1110) $\mathrm{ppm}$. The progressive decrease in amount of $\mathrm{Cd}$ absorbed by plant occurred at (3 and 4) $\mathrm{mg} / \mathrm{Kg}$ soil reaching (830 and 440)ppm respectively. Lowest level of $\mathrm{Cd}$ were accumulated in control treatment. The absorption of heavy metals is severely affected at high concentrations due to cell toxicity 
and ultimately cell death. The heavy metal must mobile into the soil solution, for the plants to accumulate them [22]. The bioavailability of metals is increased in soil through several means in which plants achieve it by secreting phytosidophores into the rhizosphere to chelate and absorb. Both acidification of the rhizosphere and exudation of carboxylates are considered potential targets for enhancing metal accumulation [14]. Metals are first bound by the cell wall with a low affinity and selectivity. Membrane transporter systems are likely to play a central role in these processes. The application of powerful genetic and molecular techniques has now identified a range of gene families that are likely to be involved in transition metal transport. These include the Heavy Metal ATPases (HMAs), the Nramps, the cation diffusion facilitator (CDF) family [13].

Table (5): Concentrations of heavy metals ions absorbed by $\boldsymbol{S}$. grandiflora whole plant

\begin{tabular}{|c|c|c|}
\hline Heavy metal & Heavy metal concentration $(\mathrm{mg} / \mathrm{Kg})$ & $\begin{array}{r}\text { Absorbed } \\
\text { concentration (ppm) }\end{array}$ \\
\hline Control & 0.0 & 80 \\
\hline \multirow{4}{*}{$\mathrm{Cd}$} & 1 & 550 \\
\hline & 2 & 1110 \\
\hline & 3 & 830 \\
\hline & 4 & 440 \\
\hline Control & 0.0 & 110 \\
\hline \multirow{4}{*}{ Co } & 15 & 220 \\
\hline & 30 & 550 \\
\hline & 45 & 470 \\
\hline & 60 & 440 \\
\hline Control & 0.0 & 250 \\
\hline \multirow{4}{*}{$\mathrm{Cu}$} & 25 & 460 \\
\hline & 50 & 620 \\
\hline & 75 & 760 \\
\hline & 100 & 890 \\
\hline Control & 0.0 & 100 \\
\hline \multirow{4}{*}{$\mathrm{Cr}$} & 25 & 800 \\
\hline & 50 & 1280 \\
\hline & 75 & 1310 \\
\hline & 100 & 880 \\
\hline Control & 0.0 & 720 \\
\hline \multirow{4}{*}{$\mathrm{Zn}$} & 100 & 1110 \\
\hline & 200 & 1350 \\
\hline & 300 & 1830 \\
\hline & 400 & 2220 \\
\hline
\end{tabular}

The concentration of Co absorbed by the whole plant increased with increasing of Co level until reaching (30)mg/Kg soil recording (550) ppm. Then a decline in Co absorbed by plant was recorded with increasing Co concentration reaching (470 and 440) ppm at (45 and 60)mg/Kg soil respectively. The amount of Co accumulated by plant recorded at (0 and 15$) \mathrm{mg} / \mathrm{Kg}$ soil was (110 and 220) ppm respectively table (5). Maximum amount 
of $\mathrm{Cr}$ absorbed by whole plant occurred at (75) $\mathrm{mg} / \mathrm{Kg}$ soil reaching (1310) ppm. A decline in the concentration of $\mathrm{Cr}$ accumulated in plant tissue at (100) $\mathrm{mg} / \mathrm{Kg}$ soil and higher reaching to (880)ppm. Levels of recorded $\mathrm{Cr}$ were $(1280,800$ and 80) at $(50,25$ and 0$) \mathrm{mg} / \mathrm{Kg}$ soil respectively. High levels of $\mathrm{Cd}$, Co and $\mathrm{Cr}$ lead to toxicity of the plant so can't be absorbed by plant at high concentrations. These results are in agreement with [3] who found that $\mathrm{Ni}, \mathrm{Co}, \mathrm{Va}, \mathrm{Cr}, \mathrm{Cd}$ are toxic elements with high levels in soils. The same table shows that the amount of $\mathrm{Cu}$ accumulated by $\mathrm{S}$. grandiflora whole plant tissue increased with increasing $\mathrm{Cu}$ concentrations. $\mathrm{Cu}$ increase with increasing $\mathrm{Cu}$ in soil because its necessary element for plant.

Maximum values of $\mathrm{Zn}$ absorbed by whole plant tissue were recorded at (400) $\mathrm{mg} / \mathrm{Kg}$ soil reaching (2220)ppm. While the lowest occurred in control treatment reaching (720)ppm then started to increase at $(100,200$ and 300) $\mathrm{mg} / \mathrm{Kg}$ soil reaching (1110, 1350 and 1830)ppm respectively. Zinc increased with increasing $\mathrm{Zn}$ in soil since it is a necessary element for plant growth and development. $\mathrm{Cu}$ and $\mathrm{Zn}$ are essential plant micronutrients and important to support cell growth, so the percentages of these two heavy metals absorbed by $S$. grandiflora plants increased with increasing of heavy metals concentrations. Plant possesses potential cellular mechanisms that may be involved in detoxification of heavy metal. These include: reduced uptake or efflux pumping of metals at the plasma membrane; chelation of metals by peptides such as phytochelatins; the repair of stress damaged proteins [14]. It is concluded from this study that S. grandiflora callus cultures and the whole plant level are tolerant to the studied heavy metals compared to other plants which their tolerance to heavy metals was documented in the literature.

\section{References}

1. Tucker, M.R.; Hardy D.H. and Stokes C.E. (2005). Heavy metals in North Carolina soils: occurrence and significance. Raleigh (NC): North Carolina Department of Agriculture and Consumer Services, Agronomic Division. 2 .

2. Iskandar, I.K. and Adriano, D.C. (1997). Remediation of soils contaminated with metals. In: Remediation of Soils Contaminated with Metals. Iskandar, A. and Adriano, D.C. (eds.). Sci. Reviews, Northwood, UK. pp:1-16.

3. Stefano, P. and Edoardo, G. (2003). Heavy metal tolerance in in vitro propagated

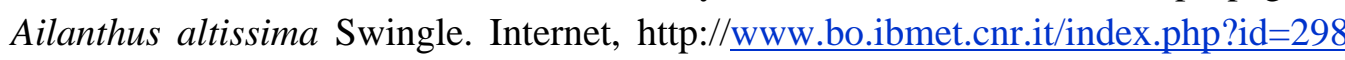
(Abstract).

4. Tal, M. (1983). Selection for stress tolerance. In handbook of Plant Cell Culture: Techniques for Propagation and breeding, vol.1. Evans, D.A.; sharp, W.R.; Ammirato, P.V. and Yamada, Y. (eds.). Macmillan Publishing Company, New York, 461-488.

5. Jain, S.; Nainawatee, H.S.; Jain, R.K. and Chowdhury, J.B. (1991). Proline status of genetically stable salt-tolerant Brassica juncea L. somaclones and their parent Prakash. Plant Cell Rep., 9: 684-687.

6. Meredith, C.P.; Conner, A.J. and Schettini, T.M. (1988). The use of cell selection to obtain novel plant genotypes resistant to mineral stresses. Iowa St. J. of Res., 62: 523-535. 
7. Onim, J.F.M. and Dzowela, B.H. (2006). The distribution of Sesbania spp in the PANESA region.

Internet hittp://www.ilri.Cgiar.org/Infoserv/webpub/fulldocs/x5491e/x5491eoa.htm.

8. Murashige, T. and Skoog, F. (1962). A revised medium for rapid growth and bioassays with Tobacco tissue culture. Physiol. Plant, 15:473-497.

9. Purohit, S.S. (2003). Laboratory Manual of Plant Biotechnology. Agro. India, pp.2429.

10. Anonymous. (1986). The Analysis of Agricultural Materials. Ministry of Agriculture, Fisheries and Food, U.K., pp 3-5.4. Atlanta, G.A. (2000). Toxicological profile for chromium. Agency for Toxic Substances and Disease Registry (ATSDR). Internet:http://www.atsdr.Cdc.gov/tfactss.html.

11. Siedlecka, A.; Krupa, Z.; Samuelsson, G.; Oquist, G. and Gardestrom, P. (1997). Primary carbon metabolism in Phaseolus vulgaris plants under $\mathrm{Cd} / \mathrm{Fe}$ interaction. Plant Physiol. and Bio., 35:951-957.

12. Abdol, K. S. (1987). Plant Growth Regulators. Al Mousul_University. Ministry of Higher Education and Scientific Research. Iraq. (In Arabic).

13. Maser, P.; Thomine, S.; Schroeder, J. I.; Ward, J. M.; Hirschi, K. Sze, H.; Talke, I. N.; Amtmann, A.; Maathuis, F. J.; Sanders, D.; Harper, J.F.; Tchieu, J.; Gribskov, M.; Persans, M. W.; Salt, D. E.; Kim, S. A. and Guerinot, M. L. (2001). Phytogenetic relationships within cation transporter families of Arabidopsis. Plant Physiol., 126:1646-1667.

14. Hall, J.L. (2002). Cellular mechanisims for heavy detoxification and tolerance. J. of Exper. Bot. 53(366):1-11.

15. Dietz, K.J.; Baier, M. and Kramer, U. (1999). Free radicals and reactive oxygen species as mediators of heavy metal toxicity in plants. In: Prasad, MNV and Hagemeyer, J. (eds.). Heavy Metal Stress in Plants: from Molecules to Ecosystems. Berlin Springer-Verlag. pp:73-97.

16. Duxbury, T. (1985). Ecological aspects of heavy metal responses in microorganisms. Adv. Microb. Ecol., 8:185-235.

17. Benavides, M.P.; Gallego, S.M.; Tomaro, M.L. and Braz, J. (2005). Cadmium toxicity in plants. Plant Physiol. 17 (1).

18. Krupa, Z.; Oquist, G. and Huner, N. P. A. (1993). The effects of cadmium on photosynthesis of Phaseolus vulgaris a fluorescence analysis. Physiol. Plant, 88:626630.

19. Li, Z. C.; Wang, D. and Wang, X. G. (2005). The protective effects of cobalt on potato seedling leaves during osmotic stress. Bot. Bull. Acad. Sci., 46: 119-125.

20. Doncheva, S.; Stoyanova, Z. and velikova, V. (2001). The influence of succinate on zinc toxicity of pea plant. J. Plant Nutr., 24:789-806.

21. Barber, S.A. (1984). Soil Nutrient Bioavailability. John Wiley and Sons, NY.

22. Lasat, M.M. (2001). The Use of Plants for the Removal of Toxic Metals from Contaminated Soil. The American Association for the Advancement of Science. USA. 